LA-7382-MS

Informal Report

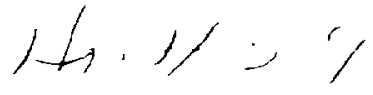

UC-80

Issued: July 1978

\title{
The Costs of Electronuclear Fuel Production
}

Theresa Flaim

Verne Loose

$\frac{\frac{\pi}{E}}{\frac{0}{0}}$

$\frac{7}{\omega}$

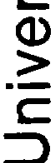




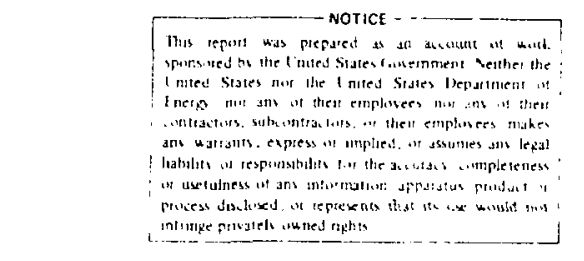

THE COSTS OF ELECTRONUCLEAR FUEL PRODUCTION

by

Theresa Flaim and Verne Loose

\begin{abstract}
The Los Alamos Scientific Laboratory (LASL) proposes to study the electronuclear fuel producer (EFP) as a means of producing fissile fuel to generate electricity. The main advantage of the EFP is that it may reduce the risks of nuclear proliferation by breeding ${ }^{23} \mathrm{U}$ from thorium, thereby avoiding plutonium separation. This is a report on the costs of eloctronuclear fuel production based upon two designs considered by LASL. Our findings indicate that the EFP design variations considered here are not likely to result in electricity generation costs as low as the uranium fuel cycle used in the US today. At current estimates of annual fuel outpht $(500 \mathrm{~kg}$ ${ }_{23{ }^{3}} \mathrm{U}$ per EFP), the costs of electricity generation using fuel produced by the EFP are more than three times higher than generating costs using the traditional fuel cycle. Sensitivity analysis indicates that electronuclear fuel production would become cost competitive with the traditional uranium fuel cycle when $\mathrm{U}_{3} \mathrm{O}_{8}$ (yellowcake) prices approach $\$ 1000$ per pound.
\end{abstract}

\section{INTRODUCTION}

The electronuclear fuel producer (EFP) is a means of producing fissile fuel for electricitygenerating nuclear reactors. The EFP has several potential advantages over alternative methods of nuclear fuel production. First, the EFP can convert thorium to fissile material $\left({ }^{23} \mathrm{U}\right)$ to fuel conventional reactors. Because thorium reserves are at least as abundant as uranium, the EFP could greatly extend the resources available for nuclear power generation." Second, by using thorium, the EFP

\footnotetext{
${ }^{\star}$ Because the demand for thorium has been small in the past, thorium reserves are not well identified. However, in 1974 the Atomic Energy Commission ostimated US thorium reserves to be 400000 tons at $\mathrm{ThO}_{2}$ prices of $\$ 10 / 1 \mathrm{~b}$. Uranium reserves were estimated to be 340000 tons at $U_{3} 0_{8}$ prices of $\$ 10 / 1 b$. Science and Public Policy Program. University of Oklahoma, "Energy Alternatives: A Comparative Analysis," prepared for the Council on Environmental Quality, et al., US Government Printing Office, Washington, DC (May 1975), pp. 6-5, 6-46.
}

avoids the production of plutonium ${ }^{*}$ and, thus, may reduce the risks of nuclear proliferation.

Electronuclear fuel production uses a linear accelerator to breed fissile material. In the design specification considered here, a high-energy proton beam (1-GeV, 300-mA) bombards a target of thorium ( ${ }^{23}$ 'Th). These high-energy protons interact with thorium, releasing a large number of neutrons. Some of these neutrons are absorbed by other thorium atoms, forming the uranium isotope ${ }^{23} \mathrm{U}$. After chemical processing, ${ }^{33} \mathrm{U}$ can be used as fuel in conventional nuclear reactors.

This paper reports an analysis of the costs of electronuclear fuel production in two design variations: (1) as a fuel producer only, and (2) as a fuel producer, self-sustaining electricity generator. The self-sustaining EFP is considered in a fuel

\footnotetext{
The EFP can also convert uranium $\left({ }^{238} U\right)$ to plutoniun $\left({ }^{239} \mathrm{Pu}\right)$. However, because of the disadvantages associated with nuclear proliferation, plutonium recovery is only considered in the traditional fuel cycle to provide a basis of comparison for the EFP with fuel reprocessing.
} 
cycle that includes fuel reprocessing. The costing of both designs presumes the sole use of thorium to produce fuel.

In order to assess the economic feasibility of the EFP, it is necessary to determine the likelihood that the EFP would result in electricity-generating costs at least equivalent to those of competing technologies. However, cost comparisons with all potential competing electricity-generating technologies are beyond the scope of this particular report. Rather, the costs of generating electricity using two types of EFP's to produce reactor fuel were compared to electricity-generating costs in the uranium fuel cycle, light-water reactor economy, both with and without fuel reprocessing. (This will be discussed in detail in the next section.) The uranium fuel cycle, light-water reactor economy without fuel reprocessing is the fuel cycle used in the US today and will also be referred to as the "traditional fuel cycle." Although these cost comparisons are based upon the use of light-water reactors, the relative costs of electronuclear fuel production and traditional uranium fuel production should remain unaffected by the reactor type so long as both processes produce equally efficient reactor fuels. Thus, relative cost comparisons based upon light-water reactors should also apply to reactors that would allow greater fuel recovery through reprocessing.

Two cost calculations were made. First, the engineering costs of electronuclear fuel production were compared with production costs in the traditional fuel cycle. Second, the present values of the costs of generating equivalent amounts of electricity were calculated for the EFP and the traditional fuel cycles. In both cost calculations, the price of $\mathrm{U}_{3} \mathrm{O}_{8}$ was varied to determine the effect of higher prices on the EFP's cost competitiveness with the traditional fuel cycle.

\section{THE EFP AND URANIUM FUEL CYCLES}

Two design variations of the electronuclear fuel producer were assessed. Case I is the fuel producer, net electricity consumer. Fuel generated in Case $I$ is mixed with ${ }^{238} U$ and burned in a oncethrough fuel cycle. Waste heat from the EFP is dissipated by cooling towers. Case $I$ is presented schematically in Fig. 1. Case II is the fueI producer, sclf-sustaining electricity generator. In Case II, ${ }^{23} \mathrm{U} \mathrm{U}$ is ailowed to build up longer in the target/blanket to produce the $1800 \mathrm{Mw}$ of heat needed to generate $600 \mathrm{MW}$ of electricity, assuming a $30 \%$ thermal efficiency. Fue1 is mixed with thorium and reprocessed. Case II is presented schematically in Fig. 2 .

The techrical characteristics of the EFP for

both Cases $I$ and $I I$ ) that were assumed in calctalating costs are as follows:

- The accelerator produces a 1-GeV, 300-ma proton beam.

- The accelerator's electricity to proton beam power conversion efficiency is $50 \%$.

- The accelerator has an $80 \%$ duty factor.

- The integrated target/blanket is composed of metalljc thorium spheres in a liquid sodiuio coolant. This "pebble-bed" design allows for the continuous loading of thorium spheres and unloading of fuel.

- Annual fuel production from the EFP is $500 \mathrm{~kg}$ ${ }^{23} \mathrm{U}$.

Fuel production and electricity-generating costs in Cases I and II were compared to electricitygenerating costs in the traditional uranium fuel cycle, which is presented schematically in Fig. 3. Electricity-generating costs for the Case II EFP with fuel reprocessing were compared to electricitygenerating costs in the uranium fuel cycle with fuel reprocessing (uranium and plutonium recyclo). The uranium fuel cycle with fuel reprocessing is presented schematically in Fig. 4.

The costs of uranium fuel production and the costs of generating electricity in the light-water reactor economy that exists today form the basis of comparison with the EFP. Capital and operating costs asscciated with a 1000-MW light-water reactor scheduled for service in the late 1980's are presented in Table I. Fuel costs were estimated for the uranium fuel cycle, with and without fuel reprocessing.

Cost factors for the Case $I$ and Case 11 electronuclear fuel producers are given in Tables II and III, respectiveIy. Both cases produce $500 \mathrm{~kg}{ }^{233} \mathrm{U}$ per year, which vould provide more than half of the 


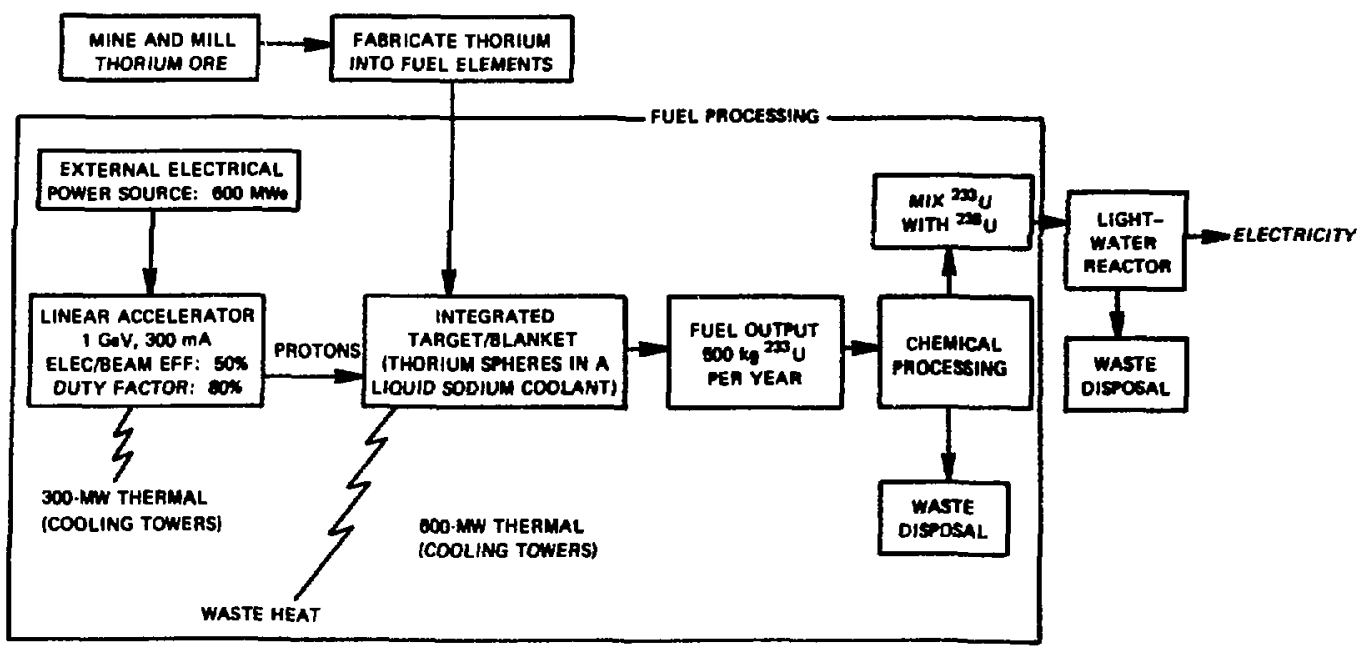

Fig. 1. Case 1 EFP: Fuel producer only, without fuel reprocessing.

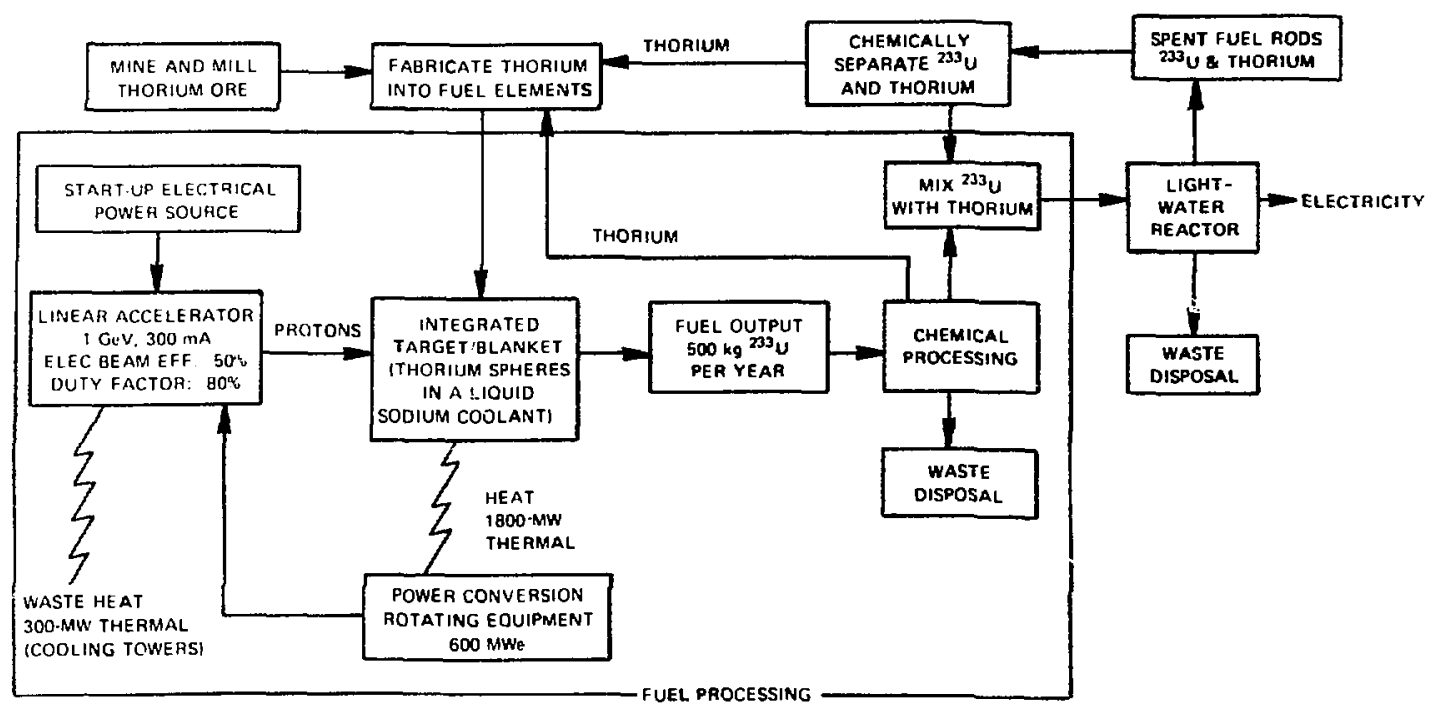

Fig. 2. Case II EFP: Fuel producer, self-sustaining electricity generator, with fuel reprocessing. In this case, ${ }^{233} \mathrm{U}$ is allowed to build up in the target/blanket in order to generate the $1800 \mathrm{MW}$ of heat needed to produce $600 \mathrm{~m}$ of electricity (assuming a 30 thermal efficiency). 


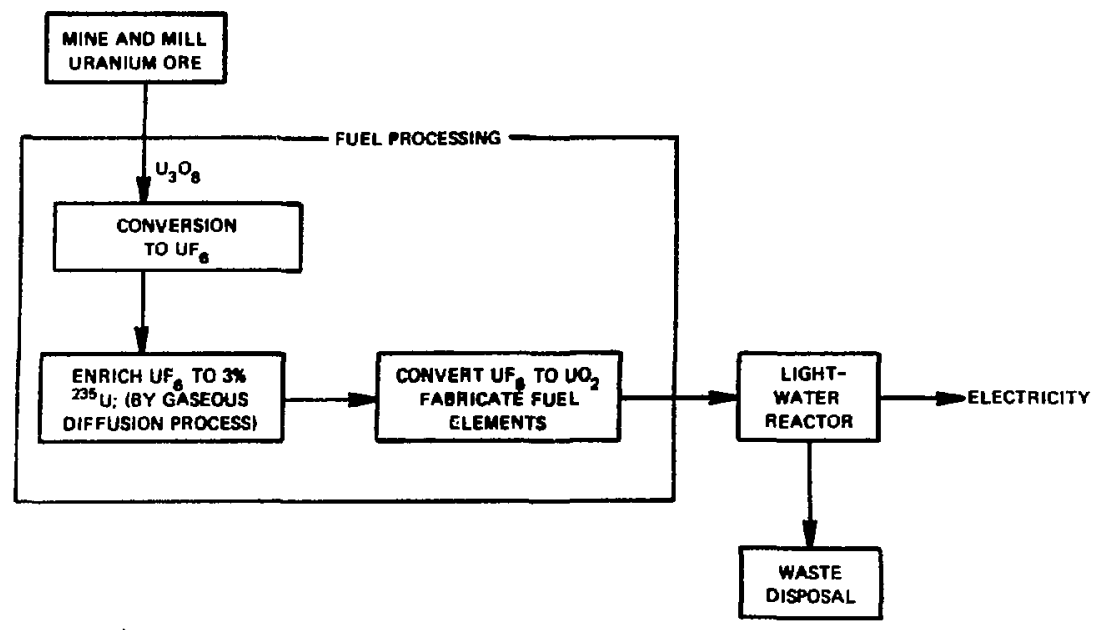

Fig. 3. Traditional uranium fuel cycle, without fuel reprocessing.

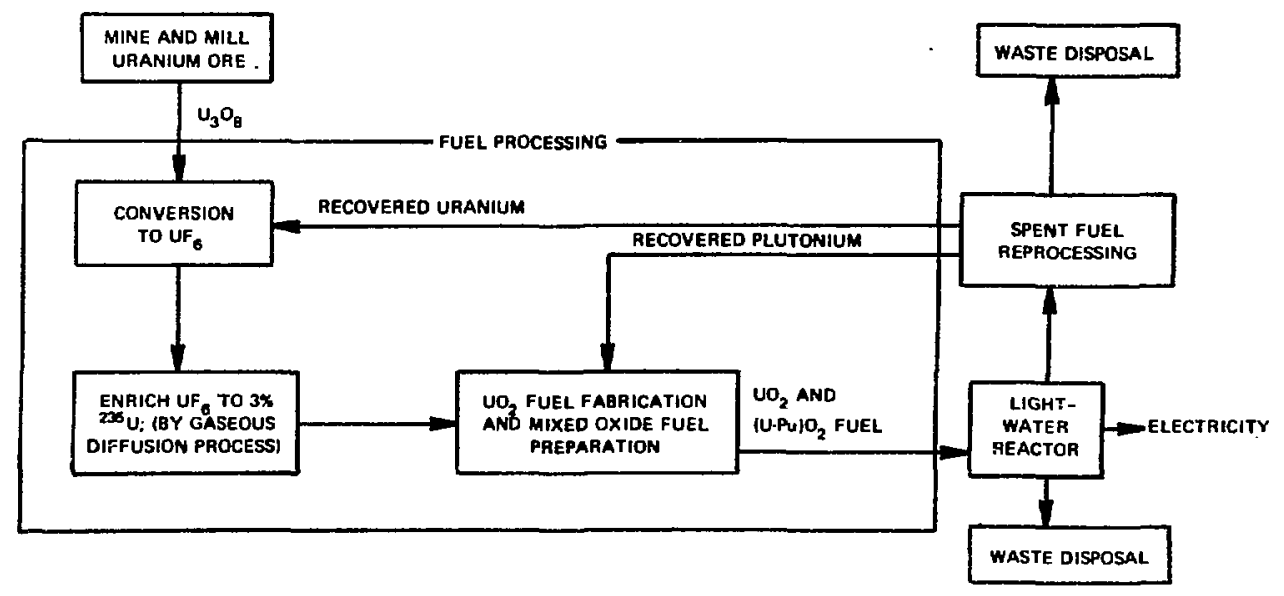

Fig. 4. Uranium fuel cycle, with fuel reprocessing (uranium and plutonium recycle). 
TABLE 1

CAPITAL AND OPERATING COSTS ASSOCIATED WITH A 1000 . MW LIGHT-WATER REACTOR SCHEDULED FOR SERVICE IN THE LATE 1980's

(1976 DOLLARS)

\section{Capital Cost}

\$649-934 million

\section{Annual Operating Costs}

Operation and maintenance

12 million

Fuel :

Without fuel reprocessing

With fuel reprocessing

33 mil1ion

27 million

Total annual operating costs: Without fuel reprocessing With fuel reprocessing
45 million 39 million

NOTE: A range of capital cost estimates exist because of regional differences within the US. The higher capital cost estimate was used for comparison. Fuel costs per year were calculated assuming (1) a $66 \%$ plant capacity factor, (2) $\mathrm{U}_{3} \mathrm{O}_{8}$ prices of $\$ 40$ per pound and (3) enrichment costs of $\$ 115$ per separative work unit (kg SWU), also assuming that 4.2 Sw are required to enrich $1 \mathrm{~kg}$ of uranium to $3.2 \% 235 \mathrm{U}(0.2 \%$ tails). Reprocessing costs were assumed to be $\$ 150 / \mathrm{kg}$ spent fuel. Light-water reactors are assumed to have a conversion ratio (the ratio of fissile material in the spent fuel to fissile material in the original fuel) of 0.51 . Thus, reprocessed uranium and plutonium will provide roughly half of the annual fuel load required for a light-water reactor (assuming 1008 of the fissile material in the spent fuel is recovered).

SOURCES: Capital and operation and maintenance costs are from C. L. Rudasill, "Coal and Nuclear Generating Costs," EPRI PS-HS5-SR Special Report, Electric Power Research Institute, Palo Alto, California (Antii 1977), pp. 24-32.

Fuel cost estimates were obtained from a variety of sources: Saunders Miller, The Economics of Nuclear and Coal Power, Praeger Pub1ishers, New York (1976), pp. 77-82; US Congress, Joint Committee on Atomic Energy, "Hearings on the Future Structure of the Uranium Enrichment Industry," Part 1, Phase 1, 93d Congress, 1st Session, US Government Printing Office, Washington, DC (July 31, 1973), pp. 39-40; Spurgeon M. Keeny, Jr., et al., "Nuclear Power Issues and Choices," Report of the Nuclear Energy Policy Study Group, Ford Foundation, Ballinger Publishing Co., Cambridge, Massachusetts (1977), pp. 109-127; Bernard L. Cohen, "The Disposal of Radioactive Wastes from Fission Reactors," Scientific Auerican, (June 1977), Vol. 236, No. 6, pp. 22-23.

TABLE II

COST FACTORS FOR THE CASE I ELECTRONUCLEAR FUEL PAODUCEN (FUEL PRODUCER ONLY)

\section{Accelerntor, Terget/Dianket}

$$
\begin{aligned}
& \text { Capital cost } \\
& \text { Annuet operating costs: } \\
& \text { Electricity } \\
& \text { Other } \\
& \text { Total operating costs }
\end{aligned}
$$

Construction period

Useful Iife of plant

Annual fuel production

Chonical Processing

\section{Capital cost}

Annual operating cost

Construction period

Useful life of plane

\section{0 million \\ 60 nillion 60 atliion \\ 120 mi11ion \\ 10 years \\ 30 years \\ $500 \mathrm{~kg}^{233} \mathrm{u}$ \\ $\$ 15$ ailion \\ 1 million \\ 10 yenrs \\ 30 years}

\begin{abstract}
The costs of chemically processing ${ }^{233} \mathrm{U}$ are based on the assumption that fuel can be processed by a separate processing plant. (It was assuand that processing facilities would not be constructed solely for the accel erator.) Capital and operating costs were obtained for a reprocessing plant havine a cepacity of 5 metrie tons of spent fuel per day. The capital cost for a plant this size is 51 billion; annual operating costs are roughly 370 aillion. Proportions of these costs were assigmed to the EFp according to the proportion of annual eapacity required to process $500 \mathrm{~kg} 233 \mathrm{U}$. proportion of annual capacity required to process $500 \mathrm{~kg} 23 \mathrm{~J}$. (Capital and operating cost estintes were obtained from Gary
Molen, Allied General Muclear Services, in a personal comenication on September 20, 1977, )
\end{abstract}

SOURCE: Los Alamos Scientific Laboratory, Electronuclear Fuel Production Task Force, Los Alanos, New Hexico (October 1977).

annual fuel load for a conventional light-water reactor without fuel reprocessing.

A11 costs are expressed in real terms using 1976 as a base year. The rationale for expressing costs in real (deflated) terms is that both general inflation and changes in relative prices should affect all cases equally because all require similar material inputs. Thus, while inflation would affect absolute costs of these cases, relative costs should remain unchanged.

\section{DIRECT COST ESTIMATION}

Engineering costs of fuel production and the present values of costs of electricity generation were estimated using the above cost data.

Engineering Cost Calculations

Engineering cost calculations allocate capital expenditures through a capital recovery factor. This calculation assumes a level, or uniform, periodic spending stream. 
TABLE III

COST FACTORS FOR THE CASE II ELECTRONUCLEAR FUEL PRODUCER (FUEL PROOUCER, SELF-SUSTAINING ELECTRICITY GENERATOR WITH FUEL REPROCESSING)

\section{Accelerator. Tarpet/Blanket}

Capital cost

Capital cost, electrictiy generation

Annual operating cost

Annual operating cost, electricicy generation

Construction period

Useful 1 ife of plant

10 years

30 years

Annual fuel production

$500 \times 8^{233} \mathrm{u}$

Chemical Processing

Capital cost

Arnual operating cost

$\$$ is nillion 1 million

Construction period

Useful life of plant

10 yenrs

30 years

Fuel Reprocessing a

Capital cose

Annual operating cost

$\$ 30$ million 2 aillion

Construction period Useful life of plant

10 years

30 years
TABLE IV

ENGINEERING COSTS OF ELECTRONUCLEAR FUEL PRODUCTION AND THE TRADITIONAL URUNIUA FUEL CYCLE (1976 DOLLARS)

\begin{tabular}{|c|c|}
\hline & Dollars/g $253 \mathrm{U}$ or ${ }^{23 S_{\mathrm{U}}}$ \\
\hline \multicolumn{2}{|l|}{ Electronuclear Fuel Production" } \\
\hline Case I (fuel producer only) & $\$ 115$ \\
\hline $\begin{array}{l}\text { Case II (self-sustaining electricity } \\
\text { genergtor) }\end{array}$ & 375 \\
\hline \multicolumn{2}{|l|}{ Traditional Uraniue Fuel Cycle } \\
\hline$U_{3} O_{8}=540 / 1 b$ & 40 \\
\hline $\mathrm{u}_{3} \mathrm{a}_{\mathrm{B}} @ \$ 100 / 1 \mathrm{~b}$ & 85 \\
\hline$U_{3} O_{8} \$ 200 / I b$. & 105 \\
\hline $\mathrm{U}_{3} \mathrm{O}_{8}=5500 / \mathrm{Ib}$ & 225 \\
\hline $\mathrm{U}_{3} \mathrm{O}_{\mathrm{g}}+1000 / 1 \mathrm{~b}$ & 425 \\
\hline
\end{tabular}

aproduction costs for electronuclear fuei production ate based upon the following information:

- Case I EFP: 1) annual capital costs, \$86 million based upon a 101 compound rate of interest, a 30 -year useful 1 ife, and a capita! recovery factor of $10.6 \%$ per year, 2) annual operating costs, $\$ 120$ million, and 3) annuaj fuel production, $500 \mathrm{~kg} 233_{\mathrm{u}}$.

${ }^{a}$ The costs of chemically processing $233_{\mathrm{y}}$ are based on the assumption that fuel can be processed by separate processing plant. (It was assumed that processing facilities would not be constructed for the accelerator itself.) Capital and operating costs were obtained for a reprocessing plant having a capacity of $S$ metric tons of spent fuel per day. The capital cost for a plant this size is $\$ I$ billion; annul operating costs are roughly $\$ 70$ million. Proportions of these costs were assigned to chenical processing and fuel reprocessing according to the proportion of annusl capecity required for each activity. (Capital and operating cost estimates were obtained from Gary Molen, Allied General Nuclear Services, in a personal communication on September 20, 1977.)

SOURCE: Los Alamos Scientific Laboratory, Electronuclear Fuel Production Task Force, Los Alamos, New Mexico (Uctober 1977).

Engineering costs of electronuclear fuel production and uranium fuel production are presented in Table IV. These calculations indicate that electronuclear fuel production costs would be approximately $\$ 400 / \mathrm{g}^{23} \mathrm{H}$. This is more than 10 times higher than current costs of $235 \mathrm{u}$ production. Sensitivity analysis indicates that electronuclear fuel production would become cost competitive with traditional uranium fuel production if $\mathrm{U}_{3} \mathrm{O}_{8}$ prices approach $\$ 1000$ per pound.

\section{Present Value of Cost Calculations}

In addition to calculating the engineering costs of fuel production, the present values of costs of generating equivalent amounts of electricity were calculated for the Case I and Case II EFP's and for the uranium fuel cycle, with and without
- Case II EFP: 1) annual capital costs, \$114 million, based upon a 101 cospound rate of interest, 30 -year useful life and capital aillion and 3) annual fuel production, $500 \mathrm{~kg} 233_{\mathrm{U}}$. tion: $4.3 \mathrm{~kg}$ Stiv are required to enrich one $\mathrm{kg} \mathrm{U}$ to $35235 \mathrm{U}$ at a 0.24 tails assay; 12 lb of $U_{3} O_{8}$ are required for $1 \mathrm{~kg}$ enriched $U^{2}$ at

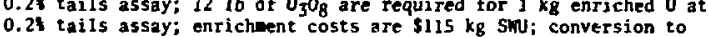
$\mathrm{UF}_{6}$ is $\$ 3.33 / \mathrm{kg}$; fabrication is $\$ 90 / \mathrm{kg}_{\mathrm{B}}$ spent fuel storage and disposal costs are $\$ 100 / \mathrm{kg}$. $\mathrm{U}_{3} \mathrm{O}_{8}$ prices were varied as show in the table. All other fuel costs relain constant.

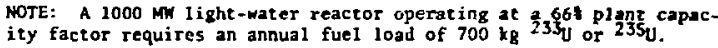

SOURCES: Los Alamos Scientific Laboracory, Electronuclear Fuel Produc:ion Task Force, Los Alamos, New Mexico (October 1977); US Congress, Joint Comittee on Atomic Enerpy, "Hearings on the Future Congress, Joint Comittee on Atomic Enerpy, "Hearings on the Future Congress, lst Session, US Governatent Printing office, Washington, Conzress, 1st Session, Us Govermaent Printing office, washington. OC (July 31,1973$)$, Pp. J9-40; Spurgeon H. Keeny, Jr, et al., Cambridge, Massachusetts (1977), pp. 109-127; Saunders Miller, The Econonics of Nuclear and Coal Power, Praeger Publishers, New York (1976). Pp. 77-82,

fuel reprocessing. * Included among the costs for the present value calculations are the costs of mining and milling ore, fuel processing, electricity generation, waste handling, and (where included) fuel reprocessing. Electricity transmission costs

"The formula for calculating present value for discrete-time discounting is:

$$
P V=\sum_{t=1}^{n} c_{t}\left[\frac{1}{(1+r)^{t}}\right] \text {, }
$$

where $\mathrm{t}=$ year, including both the construction phase and the plant's useful life,

$c_{t}=$ cost incurred in year $t$, and $\mathbf{r}=$ annual discount rate. recovery fuctor of 10.64 per year, 2) annual operating costs, $\$ 73$

braditional fuel cycle costs are based upon the following informa"Nuclear Power Issues and Choices," Report of the Nuclear Eneray Policy Study Group, Ford Foundation, Ballinger Publishing Co., 
are excluded; it was assumed that these costs are equal for all cases. Also excluded are research and development costs associated with the EFP. *

Two factors are important in calculating the present value of costs: (1) the total costs of each technology, and (2) the time profile of expenditures.* A complete estimate of total costs is obtained by insuring that all costs associated with each technology are included. The timing of expenditures is represented by discounting. Because the technologies may involve different spending streams, it is necessary to standardize them. Discounting achieves this by applying decreasing weights to expenditures of greater futurity. Consequently, calculating the present value of costs yields a single number for each technology, which is then used for comparison.

A discount rate of $10 \%$ was used to calculate the present value of costs. This discount rate reflects an estimated average real rate of return on capital (before taxes) in the private sector.

Life cycle costing of electricity generation using the EFP or the uranium fuel cycle is necessary for three reasons. First, the cases evaluated will require spending over a 30 - to 40 -year time horizon. Consequently both total costs and the timing of expenditures are important. Second, fuel cycle and olectricity generation costs must be considered because the fuel cycle will determine the

\footnotetext{
" A complete assessment of the EFP should include research and development costs. However, the difficulties of predicting these costs necessitated their exclusion. by comparing the present value of supplying electricity to the accelerator by (1) purchasing electricity, and (2) using waste heat from the target/ blanket to generate electricity directly. Purchased electricity is assumed to cost $\$ 60$ million per year, or $\$ 1.8$ billion over the accelerator's 30 -year operating life. The costs of generating electricity, as shown in Fig. 2, include capital costs of $\$ 260$ million and $\$ 13$ million per year for operating costs. Thus, total capital and operating costs for generating electricity directly are $\$ 650 \mathrm{million}$. The present value (at a $10 \%$ discount rate) of the costs of purchased electricity is $\$ 218 \mathrm{million}$ compared with $\$ 209$ million for self-generation. Thus, while the total costs of purchased and selfgenerated electricity differ by $\$ 1$ billion, the present values of costs differ by only $\$ 9$ million.
}

number of light-water reactors the EFP can supply, a crucial factor affecting its economic feasibility. Third, the Case II EFP includes fuel reprocessing; it is necessary to calculate electricity-generating costs in order to determine how fuel reprocessing in the EFP and uranium fuel cycles compares to the traditional uranium fuel cycle without fuel reprocessing.

The presont values of the costs of generating electricity in the uranium and EFP fuel cycles (with and without fuel reprocessing) are presented in Table V. Without fuel reprocessing, the present values of the costs of generating electricity using either the Case I or Case II EFP to produce reactor fuel are nearly three times greater than the present value of costs of the traditional fuel cycle. The price of $\mathrm{U}_{3} \mathrm{O}_{8}$ was assumed to be $\$ 40$ per pound in the base case. Sensitivity analysis indicates that electronuclear fuel production would result in electricity-generating costs roughly equal to the uranium fuel cycle if $\mathrm{U}_{3} \mathrm{O}_{8}$ prices reach $\$ 1000$ per pound.

With fuel reprocessing, the present value of the costs of generating electricity with the EFP is twice as high as the uranium fuel cycle. At $\mathrm{U}_{3} \mathrm{O}_{8}$ prices of $\$ 1000$ per pound, the uranium fuel cycle with reprocessing is still slightly cheaper than electronuclear fuel production.

Light-water reactors have a conversion ratio of 0.51 (the ratio of fissile material in the spent fuel to the fissile material in the original fuel). Thus, roughly half a light-water reactor's annual fuel load can be provided by fuel reprocessing. * Reactors with higher conversion ratios allow greater fuel recovery. Evaluating the effect of introducing higher converter reactors on the economic feasibility of electronuclear fuel production requires comparing electricity-generating costs of both the EFP and uranium fuel cycles when both produce fuel that is burned in higher converter reactors and fuel is reprocessed. However, so long as ${ }^{235} U$ and ${ }^{233} U$ are equally efficient fuels for reactors with higher

\footnotetext{
*This is true, assuming that $100 \%$ of the fissile material in the spent fuel is recovered. Bernard L. Cohen, "The Disposal of Radioactive Wastes from Fission Reactors," Scientific American (June 1977), Vo1. 236 , No. 6, pp. 22-23.
} 
TABLE $v$

PRESERT VALUES OF ELECTRICITY GENERATIMG COSTS FOR THE URANIUM FUEL CYCLE AND THE CASE I AND CASE II ELECTROMUCLEAR FUEL PRODUCERS (STANDARDIZED TO A 1000-M LICHT-WATER REACTOR)

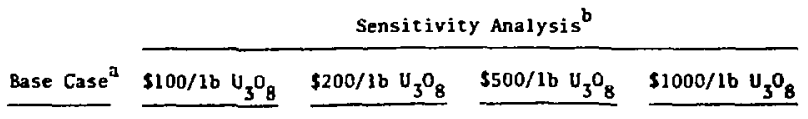

(in millions of 1976 dollars)

Without Fuel Reprocessing

Traditional uraniu fuel
cycle

Case I EFP (fuel producer on $1 y$ )

Case II EFP (self-sustaining electricity generator)

\section{$\$ 740$}

1980

1970

720

1480

\begin{abstract}
$\$ 820$
\end{abstract}
1980

1970

760

1480
$\$ 950$

1980

1970

820

1480
$\$ 1300$

1980

1970

Case II EFP (self-sustaining electricity generator\}

1480

\footnotetext{
atables I, II, and III list the base cost factors for the light-water reactor econony that exists today, the Case I EFP, and the Case II EFP. respectively. The present values of costs of the Case $]$ and Case II EFP's include the capital costs of the light-water reactors fueled by the EFP's.

${ }^{b}$ All other costs are identical to the base case. Because $238_{\mathrm{U}}$ is wixed with $233_{\mathrm{J}}$ in the Case I EFP, the present values of generating costs for the Case I EFP should also rise as $\mathrm{U}_{3} \mathrm{O}_{8}$ prices increase. However, the purpose of the sensitivity analysis was to show how the costs of electricity generation with the EFP compare to generation costs in the uraniun fuel cycle at varying $U_{3} \mathrm{O}_{8}$ prices. The reader should be aware that the present values of costs for the Case I EFP exclude higher fuel costs that would result from higher $U_{3} 0_{8}$ prices.

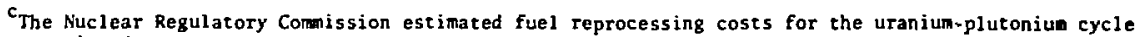
to be $\$ 150 / \mathrm{kg}$ spent fuel; this estimate was used in the above calculations. Reprocessing costs are difficult to predict at the present time and some authors feel that $\$ 200-\$ 400 / \mathbf{k g}$ spent fuel is nore realistic. Spurgeon 4 . Keeny, Jr.. et al.. "Nuclear Power Issues and Choices," Report of the Nuclear Energy Policy Study Group, Ford Foundation, Ballinger Publishing Company, Canbridge, Massachusetts (1977), p. 326 . Reprocessing costs for $233_{\mathrm{J}}$ were estimated to be roughly $\$ 110 / \mathrm{kg}$ spent fuel. Fuel is not reprocessed in the Case EFP.

NOTE: All calculations assume a 10-year construction period and that facilities (LwR's and EFP) have a useful life of 30 years. Present values of cost calculations assune the following percentages of total capital costs are spent in years 1 through 10 (construction phase), respectively: $5,10,10,15,15,15,10,10,5$, and $5 \%$. The costs of the initial light-water reactor core loading $(3000 \mathrm{~kg}$
$235_{\mathrm{U}}$ or $\left.233_{\mathrm{U}}\right)$ are excluded in the above calculations. A $1000-\mathrm{MW}$ light-water reactor oper-
ating at a $66 \%$ capacity factor consumes $22500 \mathrm{~kg}$ of fuel per year, or roughly $700 \mathrm{~kg} 235 \mathrm{U}$ or $233 \mathrm{U}$ (assuming 3.2 enrichment). Saunders Miller, The Economics of Nuclear and Coal Power, Praeger Publishers, New York (1976), p. 78 .
}

conversion ratios, the results of these cost calculations based upon light-water reactors should also apply to reactors that would allow greater fuel recovery through reprocessing.
The above analysis indicates that the electronuclear fuel producer in the design variations considered here is unlikely to result in electricity generation costs that are lower than the uranium fuel cycle, even if $\mathrm{U}_{3} \mathrm{O}_{8}$ prices increase dramatically. 